\title{
SCHISTOSOMIASIS IN ANTIQUITY
}

by

\author{
P. B. ADAMSON*
}

\section{INTRODUCTION}

SCHISTOSOMES that infect domestic animals are of great economic importance, and may even cause death in cattle and sheep. ${ }^{1}$ These parasites may also at times infest man, the most important of the several species being Schistosoma haematobium and Schistosoma mansoni. They are the subject of the present discussion.

Both these parasites have a complicated, but similar, life cycle. Mature adult male and female schistosomes inhabit the small mesenteric or pelvic veins of man, the definitive host. After fertilization, the eggs are eventually extruded into the urinary tract or the rectum, causing haemorrhage from these sites. In general, infection by $S$. haematobium tends to localize in the genito-urinary system, whereas infection by $S$. mansoni is more likely to be found in the rectum. Their mature eggs are, therefore, found either in the urine or faeces, or in the walls of the bladder or rectum. Both eggs and schistosomes may, however, be in aberrant sites, such as the internal viscera or in the superficial tissues. ${ }^{2}$ On discharge from the body, the eggs hatch out in fresh water, and the free-swimming miracidia infest snails of the family Physidae or Bulinidae for $S$. haematobium, and of the family Planorbidae for $S$. mansoni infections. These multiply asexually within the visceral mass of the snail, the alternative host, and when conditions are suitable, free-swimming larval forms, cercariae, escape into the water, penetrate the skin of the definitive host, man, and become immature schistosomes. Eventually, after passing through the lungs, they migrate to the venules of the pelvis or mesentery, where they mature in situ and lay eggs intravascularly, thus repeating their life cycle.

Natural infection by $S$. haematobium is restricted to primates, and only five cases occurring among monkeys and baboons have so far been discovered in East and West Africa; $;^{3}$ it appears to be primarily an intestinal disease in monkey hosts. ${ }^{4}$ On

*P. B. Adamson, M.D., D.T.M. \& H., Beckwith House Farm, Beckwith, Harrogate, North Yorkshire HG3 1QQ.

1 G. D. Bhalerao, 'Schistosomiasis in animals', Proc. 4th int. Congr. trop. Med. Malaria, 1948, 2: 1386-1393, see p. 1386.

2Note especially schistosomiasis in cervical smears (D. W. Shennan and M. Gelfand, 'Bilharzia ova in cervical smears in Southern Rhodesia', Trans. R. Soc. trop. Med. Hyg., 1971, 65: 95-99), in lung tissues (A. F. B. Shaw and A. A. Ghareeb, 'The pathogenesis of pulmonary schistosomiasis in Egypt, with special reference to Ayerza's disease', J. Path. Bact., 1938, 46: 401-424), in the spinal cord (J. Neves, R. P. Marinto, P. K. de Aranjo and P. Raso, 'Spinal cord complications of acute Schistosoma mansoni infestations', Trans. $R$. Soc. trop. Med. Hyg., 1973, 67: 782-792), and the liver (W. StC. Symmers, 'History on the shelf', Proc. R. Soc. Med. (Sect. Hist. Med.), 1973, 66: 1021-1022).

'M. G. Taylor, G. S. Nelson and B. J. Andrews, 'A case of natural infection of Schistosoma haematobium in a Senegal baboon (Papio sp.)', Trans. R. Soc. trop. Med. Hyg., 1972, 66: 16-17.

'A. C. Chandler and C. P. Read, Introduction to parasitology, New York, John Wiley, 1961, 10 th ed., p. 285. 


\section{Schistosomiasis in antiquity}

the other hand, $S$. mansoni lesions have been found in the intestine of baboons, which nowadays are frequently infected in parts of Kenya and Tanzania. ${ }^{5}$

It is known that schistosomiasis occurred in Ancient Egypt, and it is the purpose of this paper to present evidence which may indicate the way it entered this country and then spread throughout the countries of the Ancient Near East. Experiments on schistosomal infestation of mummies will also be reported.

\section{SCHISTOSOMIASIS IN ANCIENT EGYPT}

Egyptian medical texts do not help in identifying cases of schistosomiasis in antiquity. The âaâ disease is mentioned at least as early as the sixteenth century B.c. in several Egyptian papyri, and may be haematuria from schistosomiasis, but authorities differ widely over the interpretation of the word. ${ }^{6}$ Treatment of haematuria and of hrrw worms, which may be $S$. haematobium, was not satisfactory. ${ }^{7}$ The identification of the small adult schistosomes in human tissues remains very doubtful indeed, ${ }^{8}$ for anatomical dissections were not performed by the Ancient Egyptians.

Urinary calculi frequently occurred in Egyptian youths about the time of Galen (A.D. c.129-c.201), but they have only rarely been found in early dynastic mummies. ${ }^{\circ}$ Urinary schistosomiasis is frequently complicated by the formation of calculi, but lithiasis alone may cause haematuria. ${ }^{10}$

${ }^{5}$ G. S. Nelson, C. Teesdale and R. B. Highton, 'The role of animals as reservoirs of Bilharziasis in Africa', in G. E. W. Wolstenholme and M. O'Conner (editors), Ciba Foundation Symposium: Bilharziasis, London, J. \& A. Churchill, 1962, pp. 127-153, see pp. 142-144; p. 132, note that wild pig and wart hog may be potential sources of infection to man in Africa; A. Fenwick, 'Baboons as reservoir hosts of Schistosoma mansoni', Trans. R. Soc. trop. Med. Hyg., 1969, 63: 557-567, see pp. 566-567.

- F. Jonckheere, Une maladie égyptienne, Brussels, Fondation Égyptologique Reine Elisabeth, 1944, p. 11; G. Lefebvre, Essai sur la médecine égyptienne, Paris, Presses Universitaires de France, 1956, p. 153; P. Ghalioungui, Magic and medical science in Ancient Egypt, London, Hodder \& Stoughton, 1963, p. 56, disagrees with this diagnosis; H. Grapow, Grundriss der Medizin der Alten Agypten III: Kranken, Krankheiten und Arzt, Berlin, Akademie Verlag, 1956, p. 66, thought âaâ was probably only haematuria, as previously mentioned by B. Ebbell, 'Die ägyptischen Krankheitsnamen', Zt. Agypt. Sprach., 1927, 62: 13-20, see p. 17; J. T. Rowling, 'Urology in Egypt', in D. R. Brothwell and A. T. Sandison (editors), Diseases in antiquity, Springfield, Illinois, Charles C Thomas, 1967, pp. 532-537, see p. 535, also was doubtful if âaâ was even a parasitic disease.

7 B. Ebbell, The Papyrus Ebers, London, Humphrey Milford, 1937, see Ebers XIX.

- R. O. Steuer and J. B. de C. M. Saunders, Ancient Egyptian and Cnidian medicine, Berkeley and Los Angeles, University of California Press, 1959, p. 3; Grapow, op. cit., note 6 above, p. 65; Ebbell, op. cit., note 6 above, p. 18 .

- G. Elliot Smith and W. R. Dawson, Egyptian mummies, London, Allen \& Unwin, 1924, p. 156. Only two cases of vesical calculi and three cases of kidney stone were found in approximately 30,000 cases examined from Egypt and Nubia. No schistosomal ova were demonstrated in one of these vesical calculi. J. Bitschai, 'History of urology in Egypt', Amer. J. Surg., 1952, 83: 215-224, see p. 217. A cemetery in the Sudan dated to the first millennium B.C. had 2.1 per cent urinary calculi in the graves examined (D. R. Brothwell, 'Evidence of endemic calculi in an early community', in Brothwell and Sandison, op. cit., note 6 above, pp. 349-351). A. T. Sandison, 'Diseases in ancient societies', Scot. Soc. Hist. Med. Rep. Proc., 1968-1969, 40-46, see p. 42, considered the incidence of calculi discovered in Egyptian tombs to be too low, due to failure of archaeologists to recognize their presence in burials.

${ }^{10}$ R. Hoeppli, 'Haematuria parasitaria and urinary calculi: early indications from Africa', Acta trop. (Basel), 1972, 29: 205-217. See p. 205, S. haematobium infection favoured the formation of urinary calculi especially in Lower Egypt, but other unidentified factors were important in calculus formation; p. 210, these calculi were rare in Negroes, and there were relatively few Negroes in Lower Egypt in antiquity. 


\section{P. B. Adamson}

However, calcified ova of $S$. haematobium have been found in the kidneys of two mummies from the XXth dynasty (c. 1184-c. 1087 B.C. $)^{11}$ This is the earliest demonstration of the infestation in human tissues from Egypt or Nubia. Schistosomiasis in mummified tissues is most unlikely to have been missed by investigators, although it must be admitted that histological examination had not often been undertaken in the past.

\section{SCHISTOSOMIASIS IN CENTRAL AND EAST AFRICA}

It has been suggested that the "cradle" of schistosomes lies in the region of the African great lakes, an area in which both the parasites and their intermediate hosts are in an active state of evolution at the present time. ${ }^{12}$ It would be expected that the definitive hosts should acquire some degree of resistance to the local strain of schistosome, and indeed this may be the case regarding the naturally infected animal reservoir in central Africa. Human hosts however show less tolerance to the parasite, ${ }^{13}$ and infections tend to be clinically obvious, are often severe, and are spreading yet further into new areas of Africa, wherever irrigation schemes and agricultural projects are being developed. ${ }^{14}$ Nevertheless it should be borne in mind that asymptomatic cases of schistosomiasis may occur, ${ }^{15}$ and that today there is evidence of hybridization among these parasites. ${ }^{16}$ Spread of infection along the trade routes from central Africa, due to increased movements between peoples over a wide geographical area, has occurred since the early part of the present century. ${ }^{17}$ With the spread of disease

11 M. A. Ruffer, 'Note on the presence of Bilharzia haematobia in Egyptian mummies of the XXth dynasty (1250-1000 B.C.)' Br. med. J., 1910, i: 16; 'Bilharzia in mummies', in R. L. Moodie (editor), Studies in the paleopathology of Egypt, Chicago, University of Chicago Press, 1921, p. 150. Provisional corrected dates for the XXth dynasty are c. 1184-c. 1087 B.C., according to A. Gardiner, Egypt of the Pharaohs, Oxford, Clarendon Press, 1962, p. 446. Only six mummies were available for examination by Ruffer, and in no case had the bladder or rectum been preserved for histological examination.

${ }_{12}$ Nelson et al., op. cit., note 5 above, p. 128; C. F. A. Bruijning, 'Water, health and economic progress', Trans. R. Soc. trop. Med. Hyg., 1971, 65: suppl. S47-S52, see p. S47.

${ }^{1 s}$ F. S. McCullough and D. T. Bradley, 'Egg output stability in the epidemiology of Schistosoma haematobium: Part I', ibid., 1973, 67: 475-490; D. T. Bradley and F. S. McCullough, 'Egg output stability in the epidemiology of Schistosoma haematobium: Part II', ibid., 1973, 67: 491-500; K. S. Warren, 'Immunopathogenesis of schistosomiasis', ibid., 1972, 66: 417-432; J. A. Cook, K. S. Warren and P. Jordan, 'Passive transfer of immunity in human schistosomiasis mansoni : attempt to prevent infection by repeated injections of hyperimmune antischistosoma gammaglobulin', ibid., 1972, 66: 777-780.

14 Bruijning, op. cit., note 12 above, p. S49; V. de V. Clarke, 'The influence of acquired resistance in the epidemiology of Bilharziasis', Cent. Afr. J. Med., 1966, 12: Suppl. 1-30, see p. 1; G. S. Nelson, 'Schistosoma mansoni infection in the West Nile district of Uganda: Part II: the distribution of $S$. mansoni with a note on the probable vectors', $E$. Afr. med. J., 1958, 35: 335-344, see p. 343; T. Aidan Cockburn, 'Infectious diseases in ancient populations', Curr. Anthrop., 1971, 12: 45-62, see p. 49; W. Alves, 'Bilharziasis in Africa: a review', Cent. Afr. J. Med., 1957, 3: 123-127, see p. 125. Infestation is associated with the irrigation network of the river and not with the Nile itself.

${ }^{15}$ A. W. Woodruff, 'Helminthic infection imported into Britain', Trans. R. Soc. trop. Med. Hyg., 1970, 64: 218-219; J. S. Lehman jr., Z. Farid, J. H. Smith, S. Bassily and N. A. El-Masry, 'Urinary schistosomiasis in Egypt', ibid., 1973, 67: 384-399. Infection was also found among "healthy" soldiers from East Africa during the Second World War (K. Dewhurst, 'The tribal distribution of Bilharziasis in East Africa', J. trop. Med. Hyg., 1949, 52: 60-61).

${ }^{16}$ C. A. Wright, V. R. Southgate, H. B. van Wijk, and P. J. Moore, 'Hybrids between Schistosoma haematobium and Schistosoma intercalatum in Cameroon', Trans. R. Soc. trop. Med. Hyg., 1974, 68: 413-414.

${ }^{17}$ R. Deschiens and A. E. Delas, 'L'extension géographique de la bilharziose Schistosoma inter- 


\section{Schistosomiasis in antiquity}

into previously uninfected zones, non-immune populations are likely to become exposed to severe infection from an endemic focus of schistosomiasis. ${ }^{18}$ Once established in newly infected areas, the schistosome readily propagates its life cycle. ${ }^{19}$

There is, however, no direct evidence of this happening in antiquity. Nevertheless, under the primitive living conditions that must have existed in central Africa during the second and first millennia B.C., the inhabitants would be in close contact with wild animals, and, if they settled in agricultural communities bordering forests and streams, suitable conditions for creating foci of endemic schistosomiasis would occur, ${ }^{20}$ as they do among the present-day primitive tribes of northern Tanzania and the pygmies of the Ituri forest. ${ }^{21}$

A reservoir of natural infection of $S$. mansoni exists among the wild monkeys of East Africa at the present time, and even a few cases of $S$. haematobium infection have been found among them. ${ }^{22}$ As communities of wild monkeys tend to remain within relatively well-defined areas, limited mainly by availability of food and water, this was probably so in antiquity, and therefore the endemic area of schistosomiasis in monkeys was also probably similarly circumscribed. The very close relationship between the tribes of hunter-gatherers and the troops of monkeys strongly suggests that a nidus of infection was maintained in central Africa, both man and monkey acting indiscriminately as definitive hosts to the parasites. Troops of baboons of the Papio species congregate at drinking sites and contaminate their watering-places very readily with excreta. Being omniverous, they may even become infected by eating infected snails. ${ }^{23}$ Papio doguera, for example, regularly visits potentially infected water in East Africa. Cercopithecus species have also occasionally been seen near water, and Cercocebus galeritus is mainly ground-living, frequenting banks of streams and rivers. All these species harbour schistosomes producing intestinal lesions. ${ }^{24}$ Experimental infestations of monkeys by Schistosoma intercalatum produce

calatum en Afrique tropicale', ibid., 1969, 63: 4th Suppl. S57-S65. Spread of disease along trade routes also noted in trypanosomiasis and relapsing fever in Africa (C. M. Good, 'Salt, trade and disease: aspects of development in Africa's northern great lakes region', Int. J. Afr. hist. Stud., 1972, 5: 543-586, see pp. 572, 582).

18 Bruijning, op. cit., note 12 above, p. S49; Clarke, op. cit., note 14 above; Alves, op. cit., note 14 above.

$19 \mathrm{G}$. Macdonald, 'Dynamics of helminth infections with special reference to schistosomes', Trans. R. Soc. trop. Med. Hyg., 1965, 59: 489-506, see p. 501. Note that a minimum amount of infected material suffices to maintain endemic schistosomiasis in a given area.

${ }^{20}$ Ibid; Cockburn, op. cit., note 14 above, pp. 48-49.

21 F. J. Bennett, I. G. Kagan, N. A. Barnicot, and J. C. Woodburn, 'Helminth and protozoal parasites of the Hadza tribe of Northern Tanzania', Trans. R. Soc. trop. Med. Hyg., 1970, 64: 857-880.

${ }^{22}$ A. Fenwick, op. cit., note 5 above, p. 565; Taylor et al., op. cit., note 3 above; Nelson et al., note 5 above, p. 142; G. S. Nelson, 'Schistosome infections as zoonoses in Africa', Trans. R. Soc. trop. Med. Hyg., 1960, 54: 301-316, see p. 311, Table III; J. Newsome, 'Problems of fluke immunity: with special reference to schistosomiasis', ibid., 1956, 50: 258-274, see p. 260. In Papio hamadryas baboons $S$. mansoni may live for years, but $S$. haematobium dies out within a few months after infection, although viable ova are produced during this time.

23 Nelson, op. cit., note 22 above, p. 311.

24 C. A. Wright, V. R. Southgate and R. J. Knowles, 'What is Schistosoma intercalatum, Fisher 1934?', Trans. R. Soc. trop. Med. Hyg., 1972, 66: 28-64, see p. 53. Note that S. intercalatum also has Bulinus species of snail as intermediate hosts. L. Lortet and C. Gaillard, 'Mammifères: singes', in La faune momifiée de l'ancienne Égypte, Lyons, Henri Georg, 1905, Série 2, pp. 207-248, see pp. 208-209, 213-214, 220; Nelson et al., op. cit., note 5 above, pp. 137-139. 


\section{P. B. Adamson}

the same intestinal pathology. ${ }^{25} \mathrm{~S}$. haematobium is probably a somewhat late variant which has adapted better to the human than to other primate hosts. ${ }^{26}$

THE SPREAD OF SCHISTOSOMIASIS IN THE MIDDLE EAST

Journeys by Egyptians to the land of Punt, a trading emporium on the coast of East Africa, took place as early as the Vth dynasty (c.2494-c.2345 B.C.), and continued intermittently until the reign of Ramesses III (1182-1151 B.C.) of the XXth dynasty, and even later. ${ }^{27} \mathrm{~A}$ wide range of merchandise, including spices, incense, trees, animals and animal products, were imported directly into Egypt, and cargoes often included monkeys and slaves. It is significant that a "dancing dwarf", almost certainly a pygmy from central Africa, was brought into Egypt as early as the Vth dynasty (c.2494-c.2345 B.C.), ${ }^{28}$ although the northern extension of pygmy distribution in antiquity is unknown. The association of pygmies, baboons and incense trees strongly suggests connexions with the hinterland of Punt.

Early records of these journeys are brief but factual. However, one was fully documented and is portrayed on the walls of the funerary temple of Queen Hashepsowe of the XVIIIth dynasty at Deir El-Bahri; it took place during the ninth year of her reign (c.1481 B.C.). Baboons and slaves were included among the valuables she received. ${ }^{20}$ It is likely that expeditions from Punt came to the port of Sewew (s'ww) on the coast of the Red Sea, opposite to Coptos. ${ }^{30}$ The merchandise was probably unloaded there and transported overland via the Wadi Hammammant to the Egyptian capital at Thebes in Upper Egypt. Even as early as the XIth dynasty (c.2134-1991 B.C.) this was a recognized trade route. ${ }^{31}$ In the records there is no hint of a reverse trade in slaves and baboons from Egypt to Punt.

Overland trading and military expeditions from Egypt rarely penetrated far into Ethiopia, and never reached the central, western or eastern regions of Africa. During the XVIIIth dynasty (c.1575-1308 B.C.), Napata, lying near the fourth cataract of the Nile, was the limit of the Nubian viceroy's jurisdiction, ${ }^{32}$ and no merchant would dare to trade far from the protection of the Egyptian army. Even the Ethiopian kings of the XXVth dynasty (c.751-656 B.C.) were politically and culturally orientated

${ }^{25}$ Wright et al., op. cit., note 24 above, pp. $42,55$.

26 Wright et al., op. cit., note 16 above; Newsome, op. cit., note 22 above.

$27 \mathrm{~J}$. H. Breasted, Ancient records of Egypt, vols I-IV, Chicago, University of Chicago Press, 1906, Vol. I, paras. 161, 351, 360, 361, 429, 605, 618; vol. II, paras. 247, 486; vol. IV, paras. 30, 407.

${ }^{28}$ Ibid., vol. I, para. 351. A Puntite Negro slave was brought to Egypt during the IVth dynasty, c.2580 B.C. (ibid., vol. II, para. 247).

${ }_{20}$ E. Naville, Temple of Deir El-Bahari, London, Egyptian Exploration Fund, 1898, part III, pls. LXXIV-LXXVI.

${ }^{20}$ Breasted, op. cit., note 27 above, vol. I, paras. 605, 618. The overseer Enenkhet was killed while building a boat at the Red Sea coast for a journey to Punt, c. 2280 B.C. (ibid., vol. I, para. 360). Khnemhotep, during the reign of Pepi II (c. $2250-$ c. 2160 B.C.), made several journeys to Punt (ibid., vol. I, para. 361).

31 Ibid., vol. I, paras. 427, 428; A. A. Saleh, 'Some problems relating to the Puenet reliefs at Deir El-Bahari', J. Egypt. Archeol., 1972, 58: 140-158, considered that no transfer of goods took place from the sea-going boats, suggesting therefore that a waterway may have linked the Red Sea with the Nile in the XVIIIth dynasty (c. 1575-1308 B.c.).

32 Breasted, op. cit., note 27 above, vol. II, para. 1022; A. A. Saleh, 'An open question on intermediaries in the incense trade during pharaonic times', Oriental., 1973, 42: 370-382. 


\section{Schistosomiasis in antiquity}

towards Egypt, and not until the end of this dynasty (c.660 B.C.) did the area of Meroē in the south of the country become important, but by then all contact with Egypt had been lost.

If it can be accepted that central Africa was the original home of schistosomiasis, it can be argued that the disease may have spread from there to the Middle East. Thus, an infected human or animal from Punt would be taken to Thebes. As no merchant would be likely to risk buying obviously diseased merchandise, the infection must have been mild or sub-clinical. This would be quite possible, for even nowadays schistosomiasis may be missed clinically, ${ }^{83}$ and the journey between Punt and Upper Egypt was neither difficult nor lengthy. Schistosomiasis could therefore be readily transported and then infect the snail hosts at Thebes. From the cases of human disease dated to the XXth dynasty (c. twelfth century B.C.), we have a terminus post quem for the disease in Egypt. Suspicion must naturally fall on expeditions to Punt by the pharaohs of the XVIIIth (c.1575-1308 B.C.) and XXth dynasties (c.1184-1087 B.C.), who made them relatively frequently, and whose records are more detailed than those of earlier ones. Later pharaohs concentrated mainly on the importation of precious stones, metals, and animal products, although slaves and monkeys were still occasionally imported.

From Thebes, a city built on the banks of the relatively fast-flowing Nile, the goods were widely distributed throughout Upper and Lower Egypt, so that any imported schistosomal infection could be quickly spread throughout the country. The presence of $S$. haematobium ova in human mummified tissues suggests that the initial infection may have been of human origin. The infection today in Upper Egypt is limited to $S$. haematobium, a mixture of $S$. mansoni and $S$. haematobium only being found in Lower Egypt, and this was probably so in the past. ${ }^{34}$ Schistosomiasis is more likely to be associated with the continuous form of irrigation which was, and still is, practised in Lower Egypt, whereas basin irrigation in Upper Egypt led to periodic drying of the land and death of the parasite. ${ }^{35}$

Infection by $S$. mansoni has still not been identified histologically in Ancient Egyptian material, but it was probably introduced into Upper Egypt by infected baboons, and although unable to establish itself there, the parasite was carried downriver to infest snails and human hosts in the Delta region of the Nile.

Although apes and baboons were not native to Lower Egypt, they were certainly known there from early times; they were, however, indigenous in the Land of Cush, which corresponded to Ethiopia of the classical writers, ${ }^{36}$ being concentrated mainly in the upper reaches of the Nile. An alabaster cynocephalic statuette bearing the name of King Narmer and dated c.3200 B.C., has been found in Egypt. ${ }^{37}$ It is now

\footnotetext{
Woodruff, op. cit., note 15 above.

s4 Chandler and Read, op. cit., note 4 above, pp. 286-287. Snail hosts of $S$. haematobium, being feeders on the bottom, are relatively unaffected by the rate of flow of the river. Snail hosts of $S$. mansoni, being surface feeders, cannot establish themselves until the current has greatly diminished.

${ }^{25}$ P. Ghalioungui, 'Parasitic disease in Ancient Egypt', Bull. Inst. Egypte, 1969, 48: 13-26, see p. 17.

${ }^{26}$ Diodorus Siculus, The Library of History, Loeb Classical Library, London, W. Heinemann, 1961, book 3.35.4-5; Herodotus, The History, Loeb Classical Library, London, W. Heinemann, 1946, book 2.29-30; L. P. Kirwan, 'Nubia and Nubian origins', Geogr. J., 1974, 140: 43-51, see p. 46.

${ }^{87}$ H. Ranke, The art of Ancient Egypt, Vienna, Phaidon Press, 1936, pl. 48-49.
} 


\section{P. B. Adamson}

generally accepted that Narmer was the king Mēnēs of the first dynasty, who united the two kingdoms of Upper and Lower Egypt under one rule. A pet Cynocephalus baboon is represented in the tomb of Atet, dated to the IVth dynasty (c.2613c.2498 B.C.), and a pet Cercopithecus monkey is shown in the tomb of Serfka at Sheikh Said, dated to the Vth dynasty (c.2494-c.2345 B.c.). ${ }^{38}$ Sacred monkeys were kept in temples in the neighbourhood of Thebes, and a cemetery for monkeys has been discovered at Gabanet el Giroud at Thebes. ${ }^{39}$ The species buried there are similar to those African species that today are known to be naturally infected with schistosomiasis, and whose ancestors presumably were transported from central Africa to Egypt. The cemetery contains mummies of Cynocephalus monkeys dating from the XVIIIth dynasty (c.1575-1308 B.C.). These animals appear to have been common in temples to Thoth, or kept as family pets by the upper social classes, preference being given to females with canine teeth removed. The cult of Thoth probably was originally established in Hermopolis Parva, a city in Lower Egypt, and the god himself may be represented as a Cynocephalus ape.

The snail hosts of schistosomiasis must have originated in Ethiopia and been carried down the Nile without the aid of man, ${ }^{40}$ particularly the Bulinus species which act as alternative hosts for $S$. haematobium. Once having reached the inhabited areas of Upper Egypt, man in his travels down the Nile would assist the snail in its wider dissemination throughout the Delta region. Once $S$. haematobium had been established in Thebes, there would be no need for additional infected human or animal material from Punt to maintain its life cycle. ${ }^{41}$

Tuthmosis III (c.1490-c.1436 B.c.), a warrior king, made numerous expeditions into Syrio-Palestine and even reached the Upper Euphrates. His immediate successors in the XVIIIth dynasty, by military or by peaceful means, continued to operate there. Every opportunity, therefore, was given for the spread of schistosomiasis from Lower Egypt into Syrio-Palestine, and, by the trade route of the "Fertile Crescent", the disease could then have penetrated easily into Mesopotamia.

There is no positive evidence that schistosomiasis did in fact occur in SyrioPalestine, all the evidence being entirely circumstantial. A monkey amulet has been discovered in the Eye Temple at Brak in northern Syria, dated to the Jemdat Nasr period, which was slightly earlier than the first dynasty of Egypt (i.e. before c.3200 B.C.). ${ }^{42} \mathrm{~A}$ shell of the snail host, Bulinus truncatus, has been discovered in a Middle Bronze Age stratum (c.1650 B.C.) at Jericho, ${ }^{48}$ and $S$. haematobium may have been

\footnotetext{
38 W. R. Dawson, 'Pygmies, dwarfs and hunchbacks in Ancient Egypt', Ann. med. Hist., 1927, 9: $315-326$, see figs. 3 and 33 .

s9 Lortet and Gaillard, op. cit., note 24 above, pp. 239-248. Another necropolis for monkeys may be located at Hermopolos, but this has apparently not yet been fully investigated.

${ }^{10}$ Nelson et al., op. cit., note 5 above, pp. 128, 153; C. A. Wright, in Wolstenholme and Conner, op. cit., note 5 above, p. 153, discussion.

¿1 Macdonald, op. cit., note 19 above. A focus of infection had been established near Thebes by c. 1200 B.C. (T. Aidan Cockburn, Paleopathol. Newsl., No. 9, March 1975).

${ }^{12}$ M. E. L. Mallowan, 'Excavations at Brak and Chagar Bazar', Iraq, 1947, 9: 1-259, see p. 103, pl. XI, No. 2 (G41S), cynocephalic amulet; Twenty-five years of Mesopotamian discovery (19321956), London, British School of Archaeology in Iraq, 1956, p. 30.

43 H. E. Biggs, 'Mollusca from prehistoric Jericho', J. Conch., Lond., 1960, 24: 379-387, see pp. 384-385.
} 


\section{Schistosomiasis in antiquity}

endemic in the region of Jericho from the time of Joshua (thirteenth century B.C.). ${ }^{44}$ The plague of the Philistines described in the Old Testament may have been an infection by $S$. mansoni, ${ }^{45}$ but this is considered unlikely by other authorities, who think that bubonic or pneumonic plague may be a more probably diagnosis. ${ }^{46}$

Similarly, there is no direct evidence that schistosomiasis occurred in Ancient Mesopotamia. Apes were not among the native Mesopotamian fauna, although they were known there from very early times. ${ }^{47}$ Akkadian medical texts, some of which were copied from earlier ones of the early part of the second millennium B.C., are usually of little value for making an accurate diagnosis of this disease. The mușâdisease in Mesopotamia may have been a genito-urinary form of schistosomiasis associated with cystitis, ${ }^{48}$ but this diagnosis is doubtful. Urinary lithiasis, often associated with schistosomiasis, has not yet been found in Ancient Mesopotamian burials, although it is clearly mentioned in medical texts. Haematuria and bloodstained diarrhoea, both of which may be found in cases of schistosomiasis, are also mentioned in these texts, but diagnosis remains uncertain due to lack of additional medical evidence. A close relationship has been noted between human habitations and shells of the snail B. truncatus at Tell Uqair, Dur Kurigalzu and Babylon from c. 3500 B.C. to 600 B.C., although no human cases of schistosomiasis have yet been discovered at archaeological sites in these parts of modern central Iraq. ${ }^{40}$ Snail shells were frequently incorporated there in mud building-bricks, and it was obligatory to use fresh water for religious ceremonies in the temples.

Infestation of Upper Egypt during the fifteenth or fourteenth centuries B.C. would allow ample time for the disease to be disseminated in Lower Egypt, and thence to become established in Palestine by the time of Joshua (late thirteenth century B.C.), and to extend into central Mesopotamia by the time of the later Kassite rulers (i.e. after the thirteenth century B.C.). The endemic nidus of schistosomiasis in the area of Thebes merely confirms the establishment of this disease in Upper Egypt by the XXth dynasty (c.1184-1087 B.C.) and does not exclude the possibility that the disease was present in earlier times.

The snail hosts, having reached the Nile Delta, would be transported overland via Palestine, Syria and the valley of the Euphrates into central Mesopotamia. It is probable that the migration of Bulinus took place in predynastic times, as evidenced by shells found at Tell Uqair in Mesopotamia from the late part of the fourth mil-

4 E. V. Hulse, 'Joshua's curse and the abandonment of ancient Jericho: schistosomiasis as a possible medical explanation', Med. Hist., 1971, 15: 376-386.

${ }^{45}$ H. H. Mollaret, 'L'arche d'alliance et la maladie des Philistins', Presse méd., 1969, 77: 2111-2114.

6 J. Preuss, Biblisch-Talmudische Medizin, Berlin, S. Karger, 1911, pp. 175-178; S. H. Blondheim, 'The first recorded epidemic of pneumonic plague: the Bible, 1 Sam. VI', Bull. Hist. Med., 1955, 29: 337-345; J. Callot, 'La peste des Philistins n'est pas non plus la bilharziose', Presse méd., 1970, 78: 615; W. P. MacArthur, 'Bubonic plague among the Philistines', Trans. R. Soc. trop. Med. Hyg., 1952, 46: 209. But note Josephus, Jewish Antiquities, Loeb Classical Library, London, W. Heinemann, 1958, book VI. 1-16, which suggests dysentery.

${ }^{47}$ E. D. van Buren, 'Mesopotamian fauna in the light of monuments', Arch. Orientforsch., 19361937, 11: 1-37, see p. 19.

${ }^{4} \mathrm{~J}$. V. Kinnier Wilson, 'Organic diseases of Ancient Mesopotamia', in Brothwell and Sandison, op. cit., note 6 above, pp. 191-208, see p. 196.

40 A. Zakaria, 'Historical study of Schistosoma haematobium and its intermediate host, Bulinus truncatus, in central Iraq', J. Fac. Med. Baghdad, 1959, 1: 2-10. 


\section{P. B. Adamson}

lennium B.C. Their route may provide additional indirect evidence of an overland trade connexion between Egypt and Mesopotamia in early dynastic times, or perhaps even earlier. ${ }^{.0}$

\section{EXPERIMENTS ON MUMMIFICATION AND DISCUSSIONS ON THEM}

During the preparation of the human body for mummification, the internal organs were removed and deposited in canopic jars dedicated to the four Children of Horus. whose representations were shown on the stoppers. Curiously enough, these jars are not mentioned by Herodotus or Diodorus Siculus, ${ }^{51}$ but they were obviously of considerable importance in the rite of mummification, for the contents were necessary to the dead person in the life after death. They were, however, frequently represented or mentioned in papyri of the Book of the Dead..$^{52}$ In preparation of the body, the heart was invariably, and the kidneys usually, left in situ. ${ }^{53}$ From the XXIst dynasty (c.1087-945 B.C.), canopic jars were often not used, four individual parcels of the viscera being wrapped in linen and replaced inside the abdominal cavity. Later still, when the standards of mummification had declined, simulated bundles of viscera were used.

Attempts at mummification probably date from the first dynasty (c.3200-c.3000 B.C.), ${ }^{54}$ but the art had developed to such an extent by the IVth dynasty (c.2620-2343 B.C.), that tissues were adequately preserved even when the corpse had been buried deep inside a pyramid. During the later periods of pharaonic rule, various sacred and secular animals were also mummified. ${ }^{55}$ The use of natron, a mixture of impure sodium carbonate and bicarbonate, for mummification is not disputed, but authorities differ as to whether a solution or the dry, impure salt was used. ${ }^{56}$ Although the former has occasionally been found in canopic jars, viscera usually appear to have been preserved in dry natron ${ }^{57}$ it has also been found inside the body cavity itself. The

so W. B. Emery, Archaic Egypt, Harmondsworth, Middlesex, Penguin Books, 1961, pp. 38-40; H. A. Winckler, 'Egypt before the pharaohs: new evidence from rock-drawings on pre-dynastic life', Ill. Lond. News, No. 5097, 26 December 1936, p. 1173 ; J. Sturm, 'Vorgeschichtliche Felszeichnungen', Arch. Orientforsch., 1936-1937, 11: 402-403, see p. 403 and fig. 16; H. J. Kantor, 'Further evidence, for early Mesopotamian relations with Egypt', J. Near East. Stud., 1952, 11 : 239-250. Voyages by sea between Mesopotamia and Egypt certainly occurred at least as early as the first dynasty (c.3110 c. 2900 B.C.), for the design of ocean-going ships was similar in both countries, but differed markedly from trading vessels on the Nile. Trade goods also show close artistic similarities.

${ }^{51}$ Herodotus, op. cit., note 36 above, book 2. 86-90; Diodorus Siculus, op. cit., note 36 above, book 1.91.2-7.

${ }^{62}$ E. A. W. Budge, The Book of the Dead, New York, E. P. Dutton, 1938, pp. 23, 27, 99, 101, 300, $336,338,502,505,506$.

bs Diodorus Siculus, op. cit., note 36 above, book 1.91.5; Elliot Smith and Dawson, op. cit., note 9 above, p. 146.

54 W. R. Dawson and P. H. K. Gray, Catalogue of Egyptian Antiquities in the British Museum. I: Mummies and human remains, London, Trustees of the British Museum, 1968, p. 4: BM52888.

${ }^{55}$ Lortet and Gaillard, op. cit., note 24 above, pp. 207-208, 236; Diodorus Siculus, op. cit., note 36 above, book 1.83.5.

so A. Lucas, in J. H. Harris (editor), Ancient Egyptian materials and industries, London, Edward Arnold, 1962, 4th ed., pp. 278-303; A. T. Sandison, 'The use of natron in mummification in Ancient Egypt', J. Near East. Stud., 1963, 22: 259-267; Dawson and Gray, op. cit., note 54 above, introduction: X; J. T. Rowling, 'Respiratory disease in Egypt', in Brothwell and Sandison, op. cit., note 6 above, pp. $489-493$, see p. 489.

${ }^{57}$ Lucas, op. cit., note 56 above, pp. 278-281; A. F. B. Shaw, 'Histological study of mummy of Har-Mosê, the singer of the XVIIIth dynasty (c.1490 B.C.)', J. Path. Bact., 1938, 47: 115-123. 


\section{Schistosomiasis in antiquity}

composition of natron was variable, ${ }^{58}$ and usually contaminated with resinous material.

Experiments 1. The shell of the schistosome ovum is formed from a tough polysaccharide. Ova of $S$. haematobium can be differentiated from those of $S$. mansoni and other species on morphological grounds and by differential staining methods. ${ }^{59}$

Inocula of 100 cercariae of $S$. mansoni and 380 cercariae of $S$. haematobium (Egyptian strain) were used for a mouse and a hamster respectively. After five months' incubation, they were killed and the mouse's large intestine and the hamster's bladder were mixed with dry natron, as recommended by Sandison. ${ }^{80}$ After twelve hours the tissues had already become almost dry, and unstained ova were readily recognizable under the microscope, although they were slightly distorted in appearance. Portions were removed at intervals and checked for unstained and stained ova, using carbol fuchsin-methylene blue stain. After five months and again after twenty months, the schistosomal ova were still present but slightly distorted; ova were readily recognizable and the differential staining was satisfactory.

Experiments 2. As natron did not destroy the ova of either species of schistosome after twenty months, it was decided to investigate the contents of canopic jars for evidence of ova in the residues. Scrapings from two jars were available for examination of unstained material:

(a) One jar from the burial of Qebhsennuf, No. 14235 (Flinders Petrie collection, University College, London), daughter of chantress Amon-Ast, found at the Ramasseum, Thebes, of the XXIInd dynasty (c.945-730 B.C.).

(b) One jar from the burial of Hatep, Lady of the House, No. 16417 (Flinders Petrie collection), probably from Abydos, of the XVIIIth dynasty (c.1575-1308 B.C.).

(c) A further sample was obtained from No. 28105 (Flinders Petrie collection). The material was from an unknown burial, probably of the Roman period. It was assumed to be a parcel of viscera that had been placed inside a mummy. The whole specimen was spindle-shaped and friable, about $15 \mathrm{~cm}$. long, having a slightly granular surface of uniformly pinkish-grey colour. Its surface had numerous small colonies of mould on it of recent origin. There was no linen wrapping. A sample was processed for histology and multiple sections were taken for selective staining. ${ }^{61}$

Scrapings from both canopic jars produced scanty resinous material, but no schistosomal ova were seen. The quantity of material was so scanty that it was hardly surprising that results were negative. Moreover, it was not known from which specific jars the material had been obtained, for their lids were absent.

The specimen No. 28105 was identified as human lung. There were no changes in

${ }^{58}$ Lucas, op. cit., note 56 above, p. 493 Appendix; Sandison, op. cit., note 56 above.

so R. L. Muller and M. G. Taylor, 'The specific differentiation of schistosome eggs by the ZiehlNeelson technique', Trans. R. Soc. trop. Med. Hyg., 1972, 66: 18-19; M. G. Taylor, 'What is Schistosoma intercalatum Fisher 1934?', ibid., 1972, 66: 57-59.

${ }^{\infty}$ Sandison, op. cit., note 56 above.

'1 Ibid; A. T. Sandison, 'Histological examination of mummified tissue', Stain Technol., 1955, 30: 277-283. Selective stains were used for elastic tissue and for free iron; the periodic-acid Schiff reagent was also used to stain the shell of the ovum. 


\section{P. B. Adamson}

the vessels, and no ova were found. Various lesions of the lungs of mummies have been identified previously, and although schistosomal lesions of the lung are relatively common, ${ }^{62}$ neither species of ova nor associated vessel lesions have yet been reported..$^{63}$

It seems possible to recognize schistosomal ova in mummified tissues from canopic jars, and even to identify the species. Specimens of ova of both species of schistosome are more likely to be found in jars dedicated to Qebhsnuf, a hawk-headed deity associated with the intestines, but jars dedicated to the human-headed Imsety and the dog-headed Hapi, associated with liver and lungs respectively, may also be worth examining. During examination of the contents, destruction of the material is minimal, but the sealing of the jar may be damaged. If, for any reason, the tissues have not been properly preserved, ova may still be demonstrated in residues from the bottom of the jar which is usually pointed internally, thereby facilitating the collection of a sample. Unfortunately in many cases the jars exhibited in museums are empty, and archaeological and historical data are often lacking, thus limiting the value of the investigation.

Examination of jars for ova may therefore be additional to the histological examination of mummified material. It could be undertaken in the field, and might provide a rapid means of identifying ova. It has already been suggested that examination of earth underneath unembalmed remains may provide evidence of schistosomiasis, ${ }^{64}$ and this may well be applicable to earlier Egyptian burials and to those from Mesopotamia and Palestine.

It is assumed that no further deterioration of schistosomal ova by natron would occur during the course of the ensuing centuries after mummification, and provided the preserved material remains dry, this assumption appears to be valid. Ruffer partially confirmed this by his discovery. ${ }^{65}$

\section{DISCUSSION}

It has been confirmed that human schistosomiasis was present in Egypt during the XXth dynasty (c.1184-1087 B.C.). ${ }^{66}$ But it may be that the disease had been introduced during the latter part of the XVIIIth dynasty (c.1575-1308 B.C.), which would provide us with an earlier provisional terminus ante quem. Even so, it does not completely eliminate the possibility that the disease may have been present as early as the IVth dynasty (c.2613-c.2498 B.c. $)^{67}$ although this appears unlikely. Fortunately the art of mummification was held in high esteem during the XVIIIth dynasty (c.15751308 B.C.), and mummies were therefore particularly well preserved, thereby rendering

\footnotetext{
62 Shaw and Ghareeb, op. cit., note 2 above. In 58 per cent of cases where lungs were examined at postmortem, S. haematobium ova were found; one-third of the cases showed involvement of pulmonary vessels.

es Ruffer, op. cit., note 11 above, pp. 15-16; A. R. Long, 'Cardiovascular renal disease: report of a case 3000 years ago', Arch. Path. (Chicago), 1931, 12: 92-94; Shaw, op. cit., note 57 above; Elliot Smith and Dawson, op. cit., note 9 above, p. 160; Ebbell, op. cit., note 7 above, Ebers LV; H. E. Sigerist, History of medicine, vol. I, New York, Oxford University Press, 1951, p. 62 n. 156; see also M. R. Zimmerman, Paleopathol. Newsl., No. 7, September 1974 and No. 1, March 1973; T. A. Reyman, ibid., No. 6, June 1974, A3-4.

A Biggs, op. cit., note 43 above, p. 385.

os Ruffer, op. cit., note 11 above. He identified calcified ova of $S$. haematobium.

o6 Ibid; Cockburn, op. cit., note 41 above.

${ }^{67}$ Dawson, op. cit., note 38 above, fig. 33: pet monkeys from the tomb of Atet in the Medum.
} 


\section{Schistosomiasis in antiquity}

tissues more suitable for histological examination today. It is therefore quite possible that ova of $S$. haematobium and $S$. mansoni may yet be discovered in mummies from this dynasty. Searches for them in mummified monkey tissues may be expected to produce comparable results. ${ }^{68}$

It is possible to make a few tentative statements about the social groups that were at risk to this disease in antiquity. Initial infections in the human hosts, the huntergatherers in the hinterland of Punt, were closely associated with the disease among baboons. The indigent population scraped a simple living on the fringes of forest and savanna, being in relatively close contact with the wild baboons. ${ }^{69}$ Among the Egyptians, those at risk were the servants and priests associated with baboons in the temples of Thoth at Thebes. Members of the ruling classes and their servants, when keeping monkeys as pets, were also exposed to infection; dwarfs were often employed in this task. ${ }^{70}$ Widespread infestation of the Nile Delta would affect most severely agricultural workers who were exposed to heavy and repeated cercarial attacks while working in the fields during daylight hours. Hunters and fishermen would be exposed intermittently to infection, depending on their hours of work and the season of the year. Thus, it is legitimate to consider schistosomiasis as an occupational hazard in antiquity. The lack of adequate mummified tissue from the lower social classes tends to exaggerate the role of the ruling caste in this disease. During the later dynasties, embalming was offered to all classes of society, ${ }^{71}$ but was rare in the earlier periods when schistosomiasis succeeded in establishing itself in Egypt.

All the inhabitants of Jericho were potentially at risk from the well-water, ${ }^{22}$ regardless of age or of social class, but the younger age groups appear to have suffered most from Joshua's curse. ${ }^{73}$ However, even by the ninth century B.C. the disease was probably quite patchy in its distribution in Palestine. ${ }^{74}$

In Mesopotamia, agricultural workers were repeatedly exposed to infection from snail-infested irrigation canals, but in addition, the priestly caste used fresh water for religious ceremonies in temples and palaces, and consequently were also at risk. The situation was further complicated by the capture of slaves, who may therefore have assisted in spreading the disease and introducing fresh strains of parasite. ${ }^{75}$

${ }^{68}$ Nelson et al., op. cit., note 5, p. 151 ; Lortet and Gaillard, op. cit., note 39 above.

69 L. P. Stoltz and G. S. Saayman, 'Ecology and behaviour of baboons in northern Transvaal', Ann. Transv. Mus., 1970, 26: 99-143, see p. 141. Wild baboons had probably adapted in some degree to human pursuits in South Africa.

${ }^{70}$ Dawson, op. cit., note 38 above, fig. 3.

${ }^{71}$ Herodotus, op. cit., note 36 above book 2.87-88; Diodorus Siculus, op. cit., note 36 above, book 1.91.2. Note that the mummy of Nakht, a weaver of the XXth dynasty (c. twelfth century B.C.), was in fact given embalmment (The History of Medicine Museum, 'The mummy autopsy: a preliminary report', Bull. Acad. Med. Toronto, 1974, 48: 23-28, see p. 23).

${ }^{12} 2$ Kgs. 2: 19, 21.

73 Josh. 6: 26; 1 Kgs. 16: 34.

"Naaman commented favourably on the rivers in Syria, yet was cured of leprosy in the Jordan (2 Kgs.5.12.14). The Jordan valley did not appear to be heavily infected even as late as the time of Christ, for the waters were used for baptism, a ceremony not according to the usual Jewish rites of purification, the waters of the Jordan being saline (compare Num.19:17, Matt.3:6, 16).

${ }^{75}$ Slaves were usually acquired in war, and were an integral part of ancient society. Mass movements of slaves and prisoners are shown in the following examples. Tuthmosis III of the XVIIIth dynasty (1490-1436 B.c.) obtained tribute from Retenu in Syria which included male and female slaves, as well as a chief's daughter who had her own domestic slaves in attendance (Breasted, op. cit., 


\section{P. B. Adamson}

\section{SUMMARY}

The probable route by which schistosomiasis entered Egypt is discussed. Its subsequent distribution throughout the Ancient Middle East is mentioned. Investigation of canopic jars for schistosomal ova may provide additional evidence of schistosomiasis in antiquity. Further examinations of histological material from mummies of humans and monkeys for schistosomiasis is recommended.

\section{ACKNOWLEDGEMENTS}

I wish to thank Mr. H. Furse and Dr. D. Mackenzie, both at the London School of Tropical Medicine, for technical assistance. Dr. D. Dixon of the Dept. of Egyptology, University College, London, kindly provided the Egyptian material from the Flinders Petrie collection. Dr. Edwin Clarke of the Wellcome Institute for the History of Medicine, London, gave much valuable advice about this article.

note 27 above, vol. II, para. 447); loot from Arvad and Tunip in Syria included slaves and warriors (ibid., vol. II, paras. 459, 462). Ramesses II of the XIXth dynasty (1290-1224 B.C.) also collected much tribute from Naharin in Syria, which was carried to the pharaoh on the backs of slaves (ibid., vol. III, para. 434). The Assyrian king, Arik-den-ili (1319-1308 B.c.), deported enemy soldiers from the city of Kutila, which lay approximately in the same region as Commagene, back to Assyria as slaves (D. D. Luckenbill, Ancient records of Assyria and Babylonia. Vol. I: historical records of Assyria from the earliest times to Sargon, Chicago, University of Chicago Press, 1926, p. 26, para. 69). Later still, Shalmaneser I, King of Assyria c.1280 B.C., took prisoners and booty back to Assyria (ibid., p. 40, para. 117). Tiglath-Pileser I (c.1117 B.C.) also took many prisoners from Commagene to Assyria (ibid., p. 74, para. 221). 